\title{
Pathogenic and Genetic Relatedness Among Xanthomonas axonopodis pv. allii and Other Pathovars of $X$. axonopodis
}

\author{
David H. Gent, Abdulwahid Al-Saadi, Dean W. Gabriel, Frank J. Louws, \\ Carol A. Ishimaru, and Howard F. Schwartz
}

First author: National Forage Seed Production Research Center, USDA-ARS, Department of Botany and Plant Pathology, Oregon State University, Corvallis 97330; second and third authors: Department of Plant Pathology, University of Florida, Gainesville 32611-0680; fourth author: Department of Plant Pathology, North Carolina State University, Raleigh 27695-7616; fifth author: Department of Plant Pathology, University of Minnesota, St. Paul 55108-6030; and sixth author: Department of Bioagricultural Sciences and Pest Management, Colorado State University, Fort Collins 80523-1177.

Accepted for publication 14 April 2005.

\begin{abstract}
Gent, D. H., Al-Saadi, A., Gabriel, D. W., Louws, F. J., Ishimaru, C. A., and Schwartz, H. F. 2005. Pathogenic and genetic relatedness among Xanthomonas axonopodis pv. allii and other pathovars of $X$. axonopodis. Phytopathology 95:918-925.

Xanthomonas axonopodis pv. allii is phenotypically and genetically diverse and its relationship to other $X$. axonopodis pathovars within DNA homology group 9.2 is unknown. In growth chamber experiments, disease symptoms were produced on onion only by inoculation with $X$. axonopodis pv. allii. Citrus bacterial spot symptoms were induced by X. axonopodis pvs. alfalfae, citrumelo, and allii on Duncan grapefruit and key lime. $X$. axonopodis pv. allii multiplication and persistence in Duncan grapefruit were equal to those of an aggressive strain of $X$. axonopodis pv. citrumelo, but populations of $X$. axonopodis pvs. alfalfae, betlicola,
\end{abstract}

ABSTRACT citrumelo, phaseoli, and vesicatoria were 1.3 to $4.0 \log$ units less than $X$. axonopodis pv. allii in onion. Genomic fingerprinting by repetitive sequence-based polymerase chain reaction demonstrated that $X$. axonopodis pvs. allii, alfalfae, and citrumelo are distinct from other Xanthomonas species and $X$. axonopodis pathovars, but these pathovars were indistinguishable from each other. Three genotype groups were apparent among DNA homology group 9.2 strains, and generally correspond to the aggressiveness and genotype groups previously described for $X$. axonopodis pv. citrumelo. X. axonopodis pvs. allii, alfalfae, and citrumelo appear to have recently diverged from a common ancestral strain.

Additional keywords: Allium cepa, citrus canker, Citrus aurantifolia, C. paradisi, Xanthomonas campestris pv. allii, X. campestris pv. citri E.
Xanthomonas leaf blight, caused by Xanthomonas axonopodis pv. allii, is an emerging disease of onion (Allium cepa) in the United States and the world (10). Disease symptoms are varied and include leaves with lenticular water-soaked lesions that elongate into chlorotic streaks most prominent on the flattened sides of leaves, necrosis, and tip dieback. Plants become stunted and bulb development is reduced or ceased. A bulb rot has never been reported and apparently does not occur, but yield losses related to the loss of photosynthetic area can be significant $(31,40,43)$.

A leaf blight of onion caused by a Xanthomonas sp. was described originally by Alvarez et al. (2) in Hawaii in 1978. The disease appeared in a new onion production region in Hawaii cleared from native vegetation. Attempts to isolate the pathogen from nearby plants and crops were unsuccessful, and seed transmission was speculated. Later reports have confirmed the pathogen is seedborne (36) and seed may be an epidemiologically important inoculum source (35). The pathogen has since been introduced into many onion-producing regions of the world, and Xanthomonas leaf blight has been reported from the continental

Corresponding author: H. F. Schwartz

E-mail address: howard.schwartz@colostate.edu

The use of trade, firm, or corporation names in this publication is for the information and convenience of the reader. Such use does not constitute an official endorsement or approval by the United States Department of Agriculture or the Agricultural Research Service of any product or service to the exclusion of others that may be suitable.

DOI: 10.1094/PHYTO-95-0918

(C) 2005 The American Phytopathological Society
United States $(23,28,38,41)$, the east Caribbean (31), South Africa (43), and Reunion Island, France (36,37). X. axonopodis pv. allii also causes a related disease on Welsh onion (A. fistulosum) $(11,24,35)$. Interestingly, a foliar blight of onion caused by $X$. striaformans was reported from southern Colorado in 1953 (45), and the disease description appears identical to Xanthomonas leaf blight symptomology. However, the description provided for $X$. striaformans differs from the descriptions of $X$. axonopodis $\mathrm{pv}$. allii by eight physiological characteristics $(2,45)$. Comparative studies of $X$. striaformans and $X$. axonopodis pv. allii are not possible because cultures of $X$. striaformans were not preserved.

The taxonomy of Xanthomonas strains pathogenic to Allium spp. has been in flux since 1978. The original description by Alvarez et al. (2) simply recognized the leaf blight pathogen as a Xanthomonas spp., but ensuing reports referred to the pathogen as Xanthomonas campestris $(23,28,41)$. Later, Kadota et al. (24) proposed the epithet $X$. campestris pv. allii for Xanthomonas strains recovered from diseased A. fistulosum. In independent studies, Roumagnac et al. (35) and Gent et al. (11) conducted polyphasic characterizations of a broad collection of Xanthomonas strains from Allium spp. Each discovered X. campestris pv. allii is pathogenic to A. серa, and that these strains are indistinguishable genetically, phenotypically, and pathogenically from other Xanthomonas strains recovered from A. cepa. The researchers suggested the correct species and pathovar designation should be $X$. axonopodis pv. allii to represent the true phylogenetic position of the organism.

The pathogenic capabilities and host range of $X$. axonopodis pv. allii are not clear. The host range of $X$. axonopodis pv. allii is reported in some literature as limited to Allium sp. $(2,4,35)$. How- 
ever, strains from Barbados are reportedly pathogenic to leguminous hosts such as snap bean (Phaseolus vulgaris), lima bean (Phaseolus lunatus), soybean (Glycine max), winged bean (Psophocarpus tetragonolobus), moth bean (Vigna aconitifolia), and field pea (Pisum sativum) (29), but these collections of $X$. axonopodis pv. allii from diverse sources and researchers have not been tested on all reported hosts. Some $X$. axonopodis pv. allii strains occasionally cause small, water-soaked lesions on snap bean, but lesions remain small and become necrotic within 7 days (35). Gent et al. (11) found that although typical common bacterial blight symptoms were absent on dry bean ( $P$. vulgaris), $X$. axonopodis pv. allii multiplied and attained high population levels in dry bean leaves. The bacterium may also persist epiphytically on some leguminous hosts (10).

Previous studies indicated some strains of $X$. axonopodis pvs. alfalfae and citrumelo can induce disease symptoms on alfalfa (Medicago sativa) and citrus (Citrus sp.) (9), but no studies have evaluated onion as a host of these and other $X$. axonopodis pathovars. Likewise, no studies have determined the compatibility of $X$. axonopodis pv. allii on host plants of closely related $X$. axonopodis pathovars. The relationship among these pathovars may be important for developing management strategies for the diseases these pathogens cause on their primary hosts.

The phylogenetic relationship among $X$. axonopodis pv. allii and other Xanthomonas species and pathovars has been studied, but generally only the type strains of representative Xanthomonas species and pathovars were included $(11,35)$, and pathogenicity assays of strains apparently closely related genetically were not included. The use of a single type strain to represent an entire pathovar may not be adequate to determine the true phylogenetic relationship of $X$. axonopodis pv. allii to closely related pathovars of $X$. axonopodis. Gent et al. (11) reported that some strains of $X$. axonopodis pv. allii are indistinguishable from the type strain of X. axonopodis pv. citrumelo. However, X. axonopodis pv. citrumelo is a genetically, pathogenically, and serologically diverse pathogen $(1,8,18,19,22)$. Consequently, the genetic relationships among $X$. axonopodis pv. allii and other pathovars of $X$. axonopodis remain unclear. The "axonopodis" group appears to be comprised of six distinct genetic clusters labeled as group 9.1 to 9.6 (32). X. axonopodis pv. allii repetitive sequence-based polymerase chain reaction (rep-PCR) fingerprints appear highly similar to other $X$. axonopodis pathovars within DNA homology group 9.2 (11,34), namely $X$. axonopodis pv. alfalfae and $X$. axonopodis pv. citrumelo, but characterization of a broader collection of strains is necessary to properly determine their genetic relatedness.

Knowledge of the genetic and pathogenic relationships among $X$. axonopodis pv. allii and other pathovars of $X$. axonopodis is essential to the development of effective management strategies for Xanthomonas leaf blight of onion. This study was initiated to determine the genetic and pathogenic relationships among $X$. axonopodis pv. allii and apparently closely related pathovars.

\section{MATERIALS AND METHODS}

Bacterial strains, culture, and DNA isolation. Fifty-nine strains of Xanthomonas isolated from 20 different plants species were used in this study, but only data from 39 strains are presented in detail (Table 1). The other strains were included as positive controls to assure DNA fingerprinting experiments correctly classified strains to the appropriate pathovar. Strains were routinely cultured on nutrient agar or broth during incubation at 26 to $29^{\circ} \mathrm{C}$. When recovered from onion leaf homogenates, $X$. axonopodis strains were cultured on nutrient agar amended with $60 \mu \mathrm{g} / \mathrm{ml}$ of kasugamycin and $50 \mu \mathrm{g} / \mathrm{ml}$ of cycloheximide to reduce growth of secondary organisms. The addition of these antibiotics to the nutrient agar was not essential to recover $X$. axonopodis from tissue homogenates, but all strains used in this study were resistant to both antibiotics and their addition reduced or eliminated the growth of other bacteria and fungi and simplified enumeration of the pathogens. All antibiotics were purchased from Sigma Chemical Co. (St. Louis, MO). Strains were preserved in $15 \%$ nutrient glycerol broth at $-80^{\circ} \mathrm{C}$ for long-term storage (11).

Strains were cultured in $1.5 \mathrm{ml}$ of nutrient broth for $24 \mathrm{~h}$ for DNA isolation procedures. The culture was adjusted to an optical density of 0.1 at $600 \mathrm{~nm}$ in sterile $0.02 \mathrm{M}$ potassium phosphate buffer $\mathrm{pH}$ 7.2 (PB), and DNA was isolated using the CTAB (hexadecyltrimethylammonium bromide) method (3). DNA was stored in Tris-EDTA buffer (TE [10 mM Tris, $1 \mathrm{mM}$ EDTA, pH 8.0]) at $-20^{\circ} \mathrm{C}$.

Pathogenicity and host range. Strains of $X$. axonopodis pv. allii (14 strains), $X$. axonopodis pv. citrumelo (11 strains), $X$. axonopodis pv. alfalfae (5 strains), X. axonopodis pv. betlicola $(2$ strains), and X. axonopodis pv. cyamopsidis (1 strain) were tested for pathogenicity on onion (cvs. Blanco Duro and Vantage) in growth chamber assays. Colonies of the strain to be tested were inoculated into $3 \mathrm{ml}$ of nutrient broth in $15-\mathrm{ml}$ culture tubes and were incubated at $26^{\circ} \mathrm{C}$ with vigorous shaking (250 oscillations per min) for $24 \mathrm{~h}$. The cultures were washed with sterile PB, adjusted to approximately $10^{7} \mathrm{CFU} / \mathrm{ml}$ in sterile $\mathrm{PB}$, and sprayed (Crown SpraTool; Aerovoe Industries, Inc., Gardnerville, NV) onto the foliage of 6- to 8-week-old plants to runoff with the bacterial suspension. Control plants were inoculated with sterile PB. The plants were placed in a growth chamber and incubated for 7 days with a $28^{\circ} \mathrm{C} / 24^{\circ} \mathrm{C}$ day/night temperature regimen, light intensity of $350 \mu \mathrm{Ms}^{-1} \mathrm{~m}^{-2}, 100 \%$ relative humidity, and daily misting with tap water to runoff. At least four plants were inoculated with each strain. If disease symptoms did not develop, a pinprick inoculation procedure was conducted. The youngest, fully extended leaves of 8-week-old onion plants (cv. Vantage) were pinpricked seven times at $1-\mathrm{cm}$ intervals with a 22-gauge needle bearing bacterial cells of a given $X$. axonopodis strain removed from a 72-h-old nutrient agar culture plate. The strains were grown in pure culture for inoculations and thus did not require antibiotic amendment to the nutrient agar for selection. Each pinpricked leaf area was inoculated with bacterial cells approximately equal in size to the needle tip, which consistently delivered $10^{6} \mathrm{CFU} /$ pinprick. Plants were observed daily for symptom development, and the pathogen was isolated from characteristic lesions by grinding leaf sections in $1 \mathrm{ml}$ of PB with a sterile mortar and pestle and streaking loopfuls of the homogenate onto nutrient agar. The experiment was repeated at least once for each strain.

Pathogenicity assays were conducted on key lime (Citrus aurantifolia) and Duncan grapefruit (Citrus paradisi var. Duncan) leaves with $X$. axonopodis pv. allii strains O177, JV 595, Xcu 200-2, X. axonopodis pv. citrumelo strain 3048, X. axonopodis pv. alfalfae strain KX-1, and $X$. axonopodis pv. citri strain 3213 as described previously $(6,12)$. Briefly, Xanthomonas strains were grown in peptone/yeast extract/glycerol/MOPS (PYGM) medium overnight at $28^{\circ} \mathrm{C}$, pelleted, and rinsed with sterile tap water before dilution to approximately $10^{5} \mathrm{CFU} / \mathrm{ml}$ in sterile tap water. Newly expanded leaves were inoculated by pressure infiltrating the abaxial surface to water soaking with approximately $10^{5} \mathrm{CFU} / \mathrm{ml}$ of each strain with the blunt end of a tuberculin syringe. Strains were classified as aggressive, moderately aggressive, or weakly aggressive on the basis of the extent of water soaking and necrosis (18) 7 days after inoculation. Pathogen isolations from lesions were not performed, but this assay is robust and has been used extensively to differentiate the aggressiveness groups of citrus bacterial spot pathogens $(9,12)$. Inoculations were repeated at least once.

In planta multiplication in citrus. In planta population dynamics of X. axonopodis pv. allii strain Xcu 200-2, isolated from onion in Georgia (39), and the holopathotype strain X. axonopodis 
pv. citrumelo 3048 were monitored in attached leaves of Duncan grapefruit. Strain Xcu 200-2 was selected for this study because it is phenotypically representative of most $X$. axonopodis pv. allii strains and it was among several $X$. axonopodis pv. allii strains that induced symptoms on attached leaves of Duncan grapefruit and key lime that resembled citrus bacterial spot. For inoculations, cultures of Xanthomonas strains were grown in PYGM medium overnight at $28^{\circ} \mathrm{C}(6)$, pelleted, washed with sterile tap water, and diluted to approximately $5 \times 10^{5} \mathrm{CFU} / \mathrm{ml}$ in sterile tap water saturated with $\mathrm{CaCO}_{3}$. This method for enumerating multiplication of Xanthomonas strains in citrus was selected because it is well established $(8,9,14,18,19)$. Each strain was pressure infiltrated into the abaxial leaf surface of attached grapefruit leaves using the blunt end of a tuberculin syringe so that most of the leaf was soaked. Three attached grapefruit leaves were infiltrated for each strain in a given experiment. A sterile cork borer (no. 3, approximately $0.28 \mathrm{~cm}^{2}$ ) was used to remove three leaf disks from each leaf at $0,1,5,12$, and 18 days after inoculation. These disks from each inoculated leaf were macerated together in $1 \mathrm{ml}$ of sterile tap water using a sterile mortar and pestle. The homogenate was serially diluted in sterile tap water before plating $10 \mu \mathrm{l}$ of each dilution $\left(10^{-1}\right.$ to $\left.10^{-9}\right)$ onto PYGM medium. Xanthomonas colonies were counted after incubation at $28^{\circ} \mathrm{C}$ for $48 \mathrm{~h}$. The experiment was conducted three times.

In planta multiplication in onion. Populations of strains O177, 11677, 81-23, 3048, 82.1, and 49199 of $X$. axonopodis pvs. allii, betlicola, vesicatoria, citrumelo, alfalfae, and phaseoli, respectively, were monitored in onion as described by O'Garro and

TABLE 1. Xanthomonas strains used in this study

\begin{tabular}{|c|c|c|c|c|c|}
\hline \multirow[b]{2}{*}{ Strain } & \multirow[b]{2}{*}{ Other strain designations $\mathrm{s}^{\mathrm{a}}$} & \multirow[b]{2}{*}{ Pathovar } & \multicolumn{3}{|c|}{ Origin } \\
\hline & & & Host & Location & Sourceb \\
\hline 82.1 & $\ldots$ & alfalfae & Medicago sativa & Florida & D. Gabriel \\
\hline 334 & $\ldots$ & alfalfae & M. sativa & Florida & D. Gabriel \\
\hline 676 & $\ldots$ & alfalfae & M. sativa & Florida & D. Gabriel \\
\hline $\mathrm{KX}-1$ & $\ldots$ & alfalfae & M. sativa & Florida & D. Gabriel \\
\hline A551-3 & & allii & Allium сера & Hawaii & A. Alvarez \\
\hline JV 594 & $\ldots$ & allii & A. сера & Brazil & O. Pruvost \\
\hline JV 595 & CFBP 6362 & allii & A. сера & Brazil & O. Pruvost \\
\hline $\mathrm{O} 130$ & CFBP 6363 & allii & A. сера & Colorado & H. Schwartz \\
\hline $\mathrm{O} 177$ & ATCC 504 & allii & A. сера & Colorado & H. Schwartz \\
\hline $\mathrm{F} 2: 22$ & ATCC 508 & allii & A. сера & Barbados & L. O’Garro \\
\hline $\mathrm{TX}-3$ & $\ldots$ & allii & A. сера & Texas & T. Isakeit \\
\hline TX-10 & $\ldots$ & allii & A. сера & Texas & T. Isakeit \\
\hline MAFF 311173 & $\ldots$ & allii & A. fistulosum & Japan & MAFF \\
\hline MAFF 311174 & $\ldots$ & allii & A. fistulosum & Japan & MAFF \\
\hline ATCC BAA 575 & $\ldots$ & allii & A. сера & South Africa & ARC-PPRI \\
\hline Xcu 200-2 & BD 142 & allii & A. сера & Georgia & R. Gitaitis \\
\hline Calon-1 & $\ldots$ & allii & A. сера & California & R. Gilbertson \\
\hline Calon-5 & $\ldots$ & allii & A. сера & California & R. Gilbertson \\
\hline 3213 & $\ldots$ & citri & Citrus sp. & Florida & D. Gabriel \\
\hline 3048 & ATCC 49120 & citrumelo & Citrus sp. & Florida & D. Gabriel \\
\hline 3162 & $\ldots$ & citrumelo & Citrus sp. & Florida & D. Gabriel \\
\hline 3294 & $\ldots$ & citrumelo & Citrus sp. & Florida & D. Gabriel \\
\hline 3328 & $\ldots$ & citrumelo & Citrus sp. & Florida & D. Gabriel \\
\hline 3401 & $\ldots$ & citrumelo & Citrus sp. & Florida & D. Gabriel \\
\hline 4600 & $\ldots$ & citrumelo & Citrus sp. & Florida & D. Gabriel \\
\hline 4754 & $\ldots$ & citrumelo & Citrus sp. & Florida & D. Gabriel \\
\hline 5436 & $\ldots$ & citrumelo & Citrus sp. & Florida & D. Gabriel \\
\hline 6260 & $\ldots$ & citrumelo & Citrus sp. & Florida & D. Gabriel \\
\hline 6572 & $\ldots$ & citrumelo & Citrus sp. & Florida & D. Gabriel \\
\hline 6774 & $\ldots$ & citrumelo & Citrus sp. & Florida & D. Gabriel \\
\hline 7364 & $\ldots$ & citrumelo & Citrus sp. & Florida & D. Gabriel \\
\hline 13D5 & $\ldots$ & cyamopsidis & Cyamopsis tetragonoloba & $\ldots$ & D. Gabriel \\
\hline ATCC 19312 & ICMP 312 & axonopodis & Axonopи scoparius & Colombia & ATCC \\
\hline & LMG 555 & & & & \\
\hline & NCPPB 2972 & & & & \\
\hline & ITCCF B45 & & & & \\
\hline ATCC 11677 & NCPPB 2968 & betlicola & Piper betle & India & ATCC \\
\hline ATCC 49119 & LMG 682 & phaseoli & Phaseolus vulgaris & USA & ATCC \\
\hline & NCPPB 409 & & & & \\
\hline & PDDCC 24 & & & & \\
\hline ATCC 35938 & LGM 892 & vasculorum & Saccharum officinarum & Mauritius & ATCC \\
\hline & NCPPB 2821 & & & & \\
\hline & PDDCC 5755 & & & & \\
\hline $81-23$ & $\ldots$ & vesicatoria & Capsicum аппиит & Florida & J. Jones \\
\hline 910 & $\ldots$ & vesicatoria & C. аппиит & USA & F. Louws \\
\hline ATCC 11633 & XV 23 & vesicatoria & C. аппиит & USA & ATCC \\
\hline
\end{tabular}

a ... Indicates information was unknown.

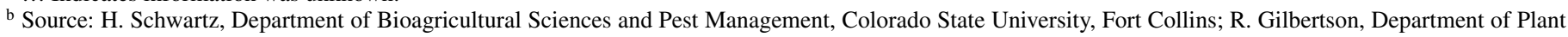
Pathology, University of California, Davis; T. Isakeit, Department of Plant Pathology and Microbiology, Texas A\&M University, College Station; L. O’Garro, Department of Biology, University of the West Indies, Bridgetown, Barbados; A. Alvarez, Department of Plant Pathology, University of Hawaii, Honolulu; R. Gitaitis, Department of Plant Pathology, University of Georgia, Tifton; D. Garbriel, Department of Plant Pathology, University of Florida, Gainesville; F. Louws, Department of Plant Pathology, North Carolina State University, Raleigh; O. Pruvost, Centre de Coopération Internationale en Recherche Agronomique pour le Dévelopement, Reunion Island, France; ARC-PPRI = Agricultural Research Council-Plant Protection Research Institute, Pretoria, South Africa; ATCC = American Type Culture Collection, Manassas, VA; CFBP = Collection Française de Bactéries Phytopathogènes, Beaucouzé Cedex, France; ICMP = International Collection of Micro-organisms from Plants, Auckland, New Zealand; LMG = Laboratorium vorr Microbiologie, Ghent, Belgium; MAFF = Ministry of Agriculture, Forestry, and Fisheries of Japan, Okinawa; NCPPB = National Collection of Plant Pathogenic Bacteria, York, United Kingdom. 
Paulraj (29). Briefly, the youngest, fully extended leaves of 8 -week-old onion plants (cv. Vantage) were pinpricked seven times at $1-\mathrm{cm}$ intervals with a 22 -gauge needle bearing a bacterial matrix of a given $X$. axonopodis strain removed from a 72-h-old nutrient agar culture plate. Each pinpricked leaf area was inoculated with a bacterial matrix approximately equal in size to the needle tip. Leaf sections $(5 \times 1 \mathrm{~cm}$ long), each having an inoculated area, were removed every 2 days, surface disinfested in $95 \%$ ethanol, rinsed in sterile PB, and ground aseptically in $1 \mathrm{ml}$ of sterile PB with a mortar and pestle. Recoveries were done up to 14 days after inoculation to generate population growth curves. The homogenate was serially diluted and plated onto nutrient agar amended with $60 \mu \mathrm{g} / \mathrm{ml}$ of kasugamycin and $50 \mu \mathrm{g} / \mathrm{ml}$ of cycloheximide. Xanthomonas colonies were enumerated after $96 \mathrm{~h}$ of incubation at $29^{\circ} \mathrm{C}$. The experiment was repeated once.

rep-PCR genomic fingerprinting. Genomic fingerprints were determined for $10,12,3$, and 1 strains of $X$. axonopodis pvs. allii, citrumelo, alfalfae, and cyamopsidis, respectively, as described by Louws et al. (25-27) using primers corresponding to prokaryotic enterobacterial repetitive intergenic consensus (ERIC) sequences, repetitive extragenic palindromic (REP) sequences, and the BOXA subunit of the BOX element. X. axonopodis pv. allii strains included in this study consisted of two strains arbitrarily selected from each of the five rep-PCR genotype groups described by Gent et al. (11). Additionally, 25 other strains of phytopathogenic xanthomonads representative of 12 of 20 Xanthomonas species described by Vauterin et al. (47) were included. Only repPCR fingerprint data from DNA homology group 9.2 and 9.3 strains are reported here.

Images were imported into GelCompar software (version 4.1; Applied Maths, Kortrijk, Belgium), linearly combined, and similarity was calculated using Pearson's correlation coefficient applied to the entire densitometric curves of the gel tracks as previously described (33). Gels were standardized with an Invitrogen Corp. (Carlsbad, CA) 1-kb DNA molecular weight ladder. Cluster analysis was performed using the unweighted pair group method with arithmetic averages clustering. All PCR reactions were repeated at least once.

\section{RESULTS}

Pathogenicity and host range. Characteristic Xanthomonas leaf blight symptoms consisting of lenticular, water-soaked lesions developed on onion within 3 to 7 days of inoculation with all $X$. axonopodis pv. allii strains tested. In one experiment,

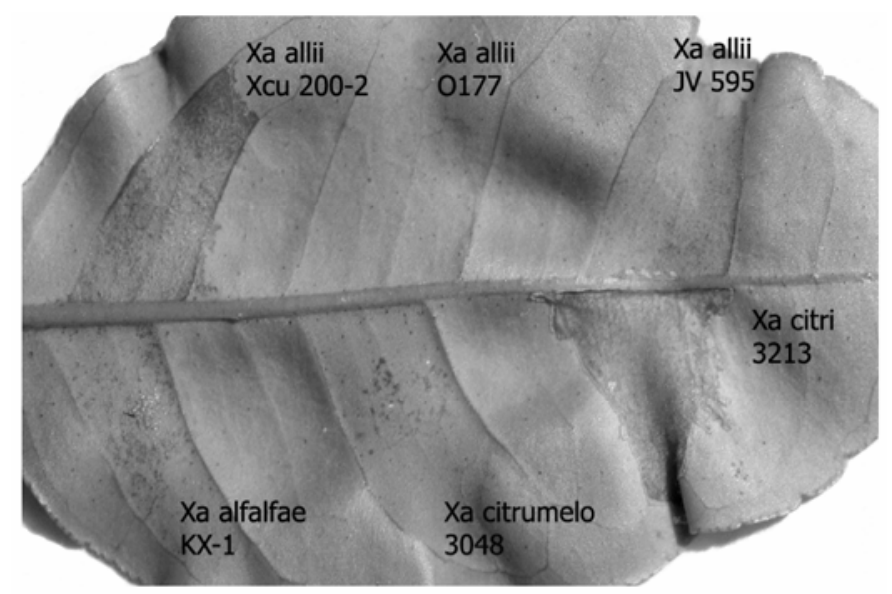

Fig. 1. Disease symptoms on Duncan grapefruit (Citrus paradisi var. Duncan) induced by different pathovars of Xanthomonas axonopodis 7 days after inoculation. Newly expanded leaves were inoculated by pressure infiltrating the abaxial surface to water soaking with approximately $10^{5} \mathrm{CFU} / \mathrm{ml}$ of each strain with the blunt end of a tuberculin syringe. Strain numbers are indicated for each pathovar of $X$. axonopodis. Xa = Xanthomonas axonopodis.
$X$. axonopodis pv. citrumelo strain 3048 induced large, watersoaked lesions on onion cv. Vantage 10 to 12 days after inoculation, and the pathogen was recovered from lesions. Attempts to isolate contaminating $X$. axonopodis pv. allii from the lesions were unsuccessful, suggesting $X$. axonopodis pv. citrumelo was the only pathogen present in these lesions. Multiple attempts to reproduce this reaction on cvs. Vantage and Blanco Duro with different inoculation techniques were not successful. No other $X$. axonopodis pathovar induced disease symptoms on onion cvs. Blanco Duro or Vantage by spray or pinprick inoculation.

Duncan grapefruit inoculated with $X$. axonopodis pv. citrumelo strain 3048 or $X$. axonopodis pv. alfalfae strain KX-1 developed characteristic citrus bacterial spot symptoms, including flattened, water-soaked lesions and necrosis (Fig. 1). Distinct but limited necrosis developed at the inoculation sites with both pathovars, and the reactions were considered to be representative of moderately aggressive citrus bacterial spot pathogens (18). X. axonopodis pv. citri strain 3213 induced typical bacterial canker symptoms of faintly chlorotic, water-soaked lesions with slightly raised edges. Three strains of $X$. axonopodis pv. allii induced varying disease symptoms on Duncan grapefruit. X. axonopodis pv. allii strain $\mathrm{O} 177$ did not induce water soaking or chlorosis in most inoculations (Fig. 1), but chlorosis was observed on Duncan grapefruit following inoculation in some experiments. This reaction was classified as weakly aggressive. Strains JV 595 and Xcu 200-2 induced chlorosis and extensive water soaking, but necrosis was limited within the water-soaked area. These reactions were classified as moderately aggressive.

On key lime, which is more susceptible to citrus bacterial spot than is Duncan grapefruit (14), X. axonopodis pv. citrumelo strain 3048 induced large, flattened, water-soaked lesions with indistinct necrosis (Fig. 2). Lesions were typical of aggressive strains of the pathogen. To a lesser degree than $X$. axonopodis pv. citrumelo strain $3048, X$. axonopodis pv. alfalfae strain KX-1 induced flattened, water-soaked lesions. The necrosis associated with $X$. axonopodis pv. alfalfae lesions was distinct from the water soaking, but was not as extensive as compared with $X$. axonopodis pv. citrumelo. Necrosis induced by $X$. axonopodis pv. alfalfae was limited to the inoculation site. The disease reaction was characteristic of moderately aggressive strains. $X$. axonopodis pv. citri strain 3213 induced typical bacterial canker symptoms of faintly chlorotic, water-soaked lesions with slightly raised edges on key lime. X. axonopodis pv. allii strains provoked disease reactions characteristic of aggressive or moderately aggressive citrus bacterial spot pathogens. Strain O177 induced water soaking and indis-

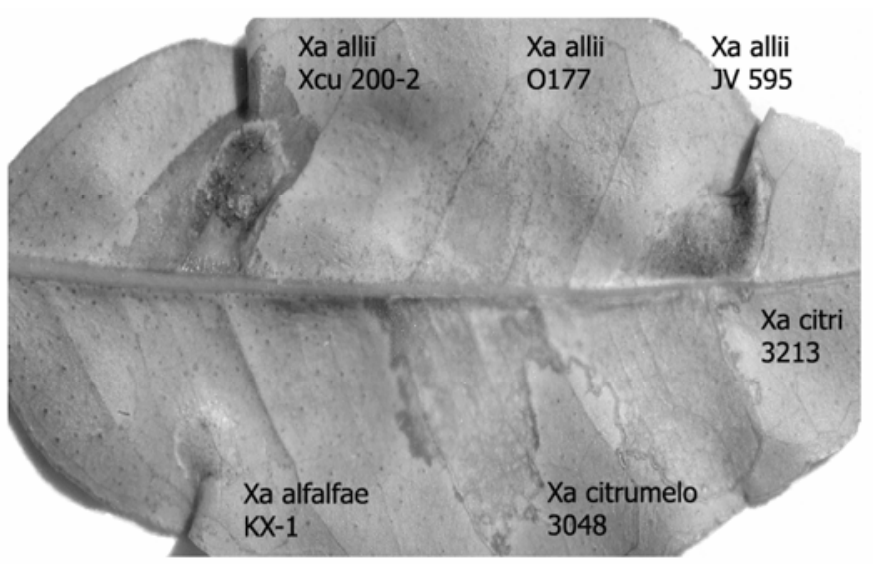

Fig. 2. Disease symptoms on key lime (Citrus aurantifolia) induced by different pathovars of Xanthomonas axonopodis 7 days after inoculation. Newly expanded leaves were inoculated by pressure infiltrating the abaxial surface to water soaking with approximately $10^{5} \mathrm{CFU} / \mathrm{ml}$ of each strain with the blunt end of a tuberculin syringe. Strain numbers are indicated for each pathovar of $X$. axonopodis. $\mathrm{Xa}=$ Xanthomonas axonopodis. 
tinct necrosis within the water-soaked lesions. The extent of water soaking was less than that induced by $X$. axonopodis pv. citrumelo, and the strain was classified as moderately aggressive. Strains JV 595 and Xcu 200-2 induced extensive water soaking that became necrotic within 7 days of inoculation, and the strains were classified as aggressive. Strain Xcu 200-2 induced more widespread water soaking as compared with JV 595, but the necrosis associated with the lesions of either strain was more extensive than that associated with the aggressive $X$. axonopodis $\mathrm{pv}$. citrumelo strain. This reaction is typical of aggressive $X$. axonopodis pv. citrumelo strains on highly susceptible citrus hosts such as key lime, and therefore, investigations of whether this reaction was a hypersensitive response were not conducted.

In planta multiplication in citrus. $X$. axonopodis pv. allii strain Xcu 200-2 was selected for in planta population dynamic studies in Duncan grapefruit because it induced clear citrus bacterial spot symptoms in pathogenicity experiments. Multiplication and survival of $X$. axonopodis pv. allii strain Xcu 200-2 was equal to that of $X$. axonopodis pv. citrumelo strain 3048 (Fig. 3). Populations of both pathogens increased nearly 100-fold over the 14-day time course of the experiment.

In planta multiplication in onion. $X$. axonopodis pv. allii populations increased linearly after inoculation into onion and increased approximately $2 \mathrm{log}$ units per leaf section (Fig. 4). Populations of $X$. axonopodis pvs. citrumelo, betlicola, and alfalfae decreased in onion 3 to 5 days after inoculation, but after this initial decline, in planta populations increased throughout the duration of the experiment. On the final sampling date, populations of $X$. axonopodis pvs. citrumelo, betlicola, and alfalfae were 1.3, 1.6, and $4.0 \log$ units per leaf section less as compared with $X$. axonopodis pv. allii, respectively. $X$. axonopodis pvs. vesicatoria and phaseoli decreased on most sampling dates after inoculation. Less than $20 \mathrm{CFU} /$ leaf section were recovered on the last sampling date, which was greater than 7 log units less than $X$. axonopodis pv. allii populations on the same date.

rep-PCR genomic fingerprinting. Complex DNA fingerprints were generated from genomic DNA extracted from all Xanthomonas species and pathovars included in this study (Fig. 5). DNA fragments of approximately $200 \mathrm{bp}$ to greater than $4 \mathrm{~kb}$ were amplified and revealed a high level of genetic diversity among $X$. axonopodis group 9.2 strains (34). DNA homology group 9.2 pathovars were clearly delineated from other DNA homology group 9 pathovars and species of Xanthomonas, but there was no clear distinction among $X$. axonopodis pvs. allii, alfalfae, and citrumelo strains that comprise group 9.2. The similarity of fingerprint profiles among these strains ranged from approximately

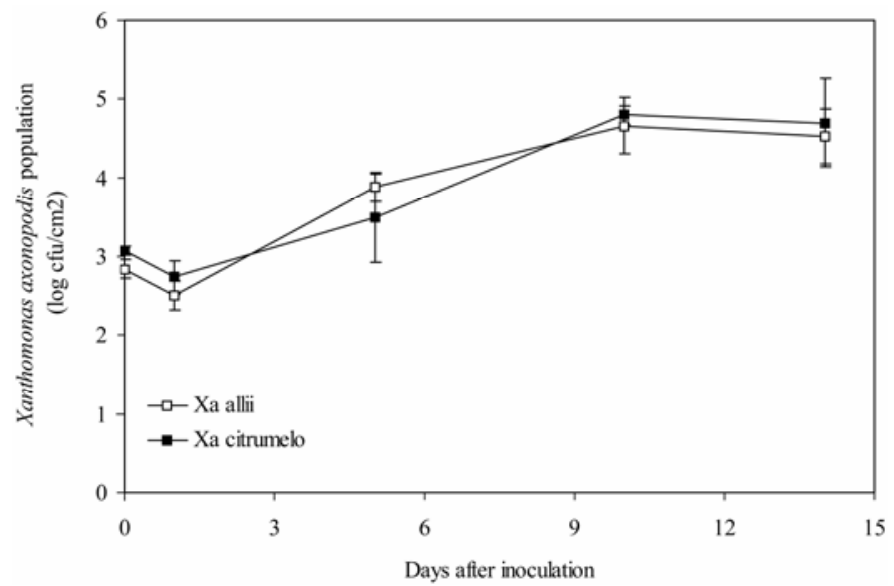

Fig. 3. Population dynamics of Xanthomonas axonopodis pv. alllii strain Xcu 200-2 and X. axonopodis pv. citrumelo strain 3048 in Duncan grapefruit (Citrus paradisi var. Duncan). Data are means of three replications repeated three times $(n=9) \pm$ standard error of the mean. Xa $=$ Xanthomonas axonopodis.
50 to $95 \%$ as determined by the product-moment correlation coefficient.

Among the 26 group 9.2 strains included in this study, some were more closely related to strains identified as belonging to another pathovar than were strains within the same pathovar. For instance, $X$. axonopodis pv. alfalfae strains 334 and 82.1 were more closely related to X. axonopodis pv. allii strain JV 594 and $X$. axonopodis pv. citrumelo strain 6774, respectively, than they were to one another. Of particular interest, $X$. axonopodis pv. allii strain $\mathrm{O} 130$ and $X$. axonopodis pv. citrumelo strain 7364 are virtually identical. $X$. axonopodis pv. allii strains included in this study generally grouped, with the exception of strain A551-3, with other $X$. axonopodis pv. allii strains belonging to the same genotype group as described by Gent et al. (11). When $X$. axonopodis pvs. citrumelo, allii, and alfalfae are considered together, three rep-PCR groups are apparent (noted in brackets in Fig. 5) and correspond approximately to the unclassified E2 and E1 restriction fragment length polymorphism (RFLP) groups differentiated by Gabriel et al. (9), respectively. Group 1 consists of four, two and one strain(s) of $X$. axonopodis pvs. citrumelo, allii, and alfalfae, respectively. Group 2 represents five $X$. axonopodis pv. citrumelo and two $X$. axonopodis pv. allii strains. Among $X$. axonopodis pv. citrumelo strains within group 2 is strain 3048, the holopathotype of the pathovar. The remaining strains were included in a heterogeneous group 3 and included three, six, and two strains of $X$. axonopodis pvs. citrumelo, allii, and alfalfae, respectively. The $X$. axonopodis pv. vesicatoria strains appeared to have distinctive rep-PCR fingerprints, clearly separating this pathovar from other group 9.2 strains included in this study.

\section{DISCUSSION}

In this study, we have established for the first time, the genetic and pathogenic relatedness of $X$. axonopodis pv. allii to other $X$. axonopodis pathovars in DNA homology group 9.2. Group 9.2 strains are distinct from other pathovars of $X$. axonopodis and Xanthomonas species but represent a heterogeneous group of genetically and pathogenically diverse plant pathogens (32). The rep-PCR did not separate the allii, alfalfae, and citrumelo pathovars, and in some cases demonstrated that the strains were genetically indistinguishable and of particular interest, and the pathovars evaluated in this study share the ability to induce bacterial spot symptoms on citrus. However, these strains can be distinguished based on their differential reaction on onion, and there-

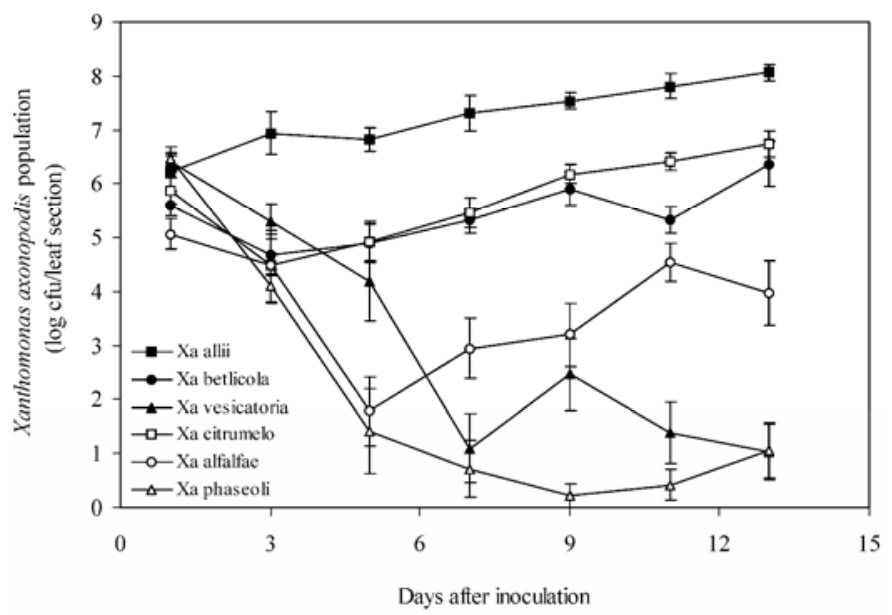

Fig. 4. Population dynamics of Xanthomonas axonopodis pathovars in onion cv. Vantage. Data are means of five replications repeated once $(n=10) \pm$ standard error of the mean. Strains O177, ATCC 11677, 81-23, 3048, 82.1, and ATCC 49119 were selected for X. axonopodis pathovars allii, betlicola, vesicatoria, citrumelo, alfalfae, and phaseoli, respectively. Xa = Xanthomonas axonopodis. 
fore, constitute discrete pathovars (7). Similarity coefficients among $X$. axonopodis pvs. allii, alfalfae, and citrumelo were at least $50 \%$ as determined by rep-PCR mediated fingerprints. Although heterogeneous, this level of similarity corresponds to at least 70\% DNA:DNA homology (32), and suggests that these strains constitute pathovars within the common species $X$. axonopodis. This study supports previous findings recommending inclusion of these pathovars as the same species $(11,35,47)$.

A limited number of strains were included in this study because most plant diseases caused by $X$. axonopodis DNA homology group 9.2 strains generally are not of economic concern, and few strains have been preserved in culture collections. Nonetheless, genomic fingerprinting of these $X$. axonopodis pathovars and strains revealed three diverse but distinct groups essentially representing the RFLP groups identified previously $(9,12)$. Group 1 contains $X$. axonopodis pv. allii strains representing $X$. axonopodis pv. allii rep-PCR genotype 3 (11) and $X$. axonopodis pv. citrumelo strains that were unclassified by RFLP analysis (9). $X$. axonopodis pv. citrumelo strains within this group are weakly aggressive to Citrus sp. and are not known to carry extrachromosomal plasmids (9). Strains that cluster within group 2 of this study included $X$. axonopodis pv. allii rep-PCR genotype 1 (11) and $X$. axonopodis pv. citrumelo RFLP group E2 strains, including the holopathotype (9). The $X$. axonopodis pv. citrumelo strains in this group are highly aggressive to citrus hosts and share a $41-\mathrm{kb}$ plasmid $(9,18,19)$ as well as common antigens (1). Many,

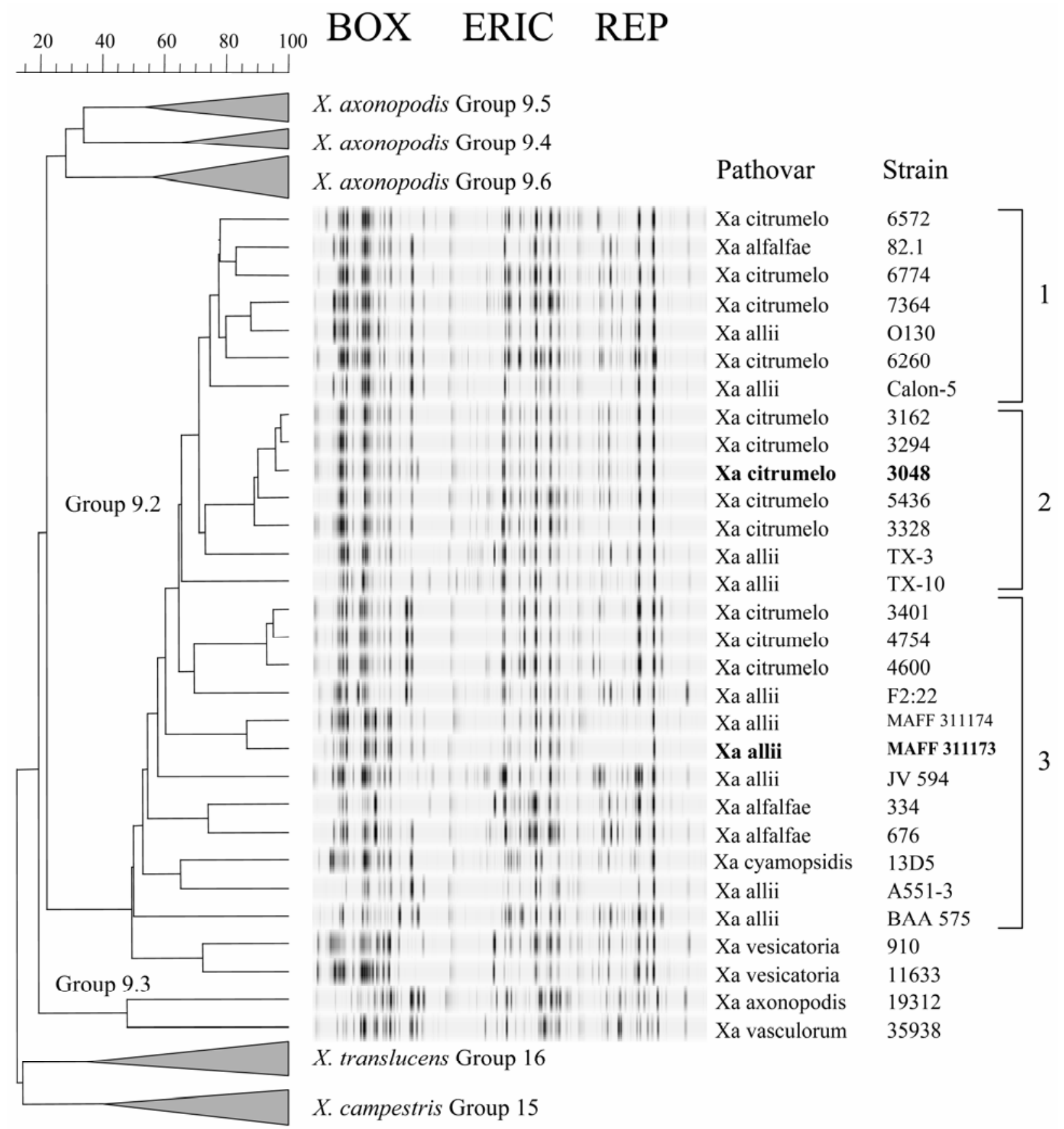

Fig. 5. Similarity among repetitive sequence-based polymerase chain reaction-mediated DNA fingerprints of Xanthomonas axonopodis strains within DNA homology 9.2 and other Xanthomonas species and pathovars. DNA fingerprints were generated using primers corresponding to prokaryotic enterobacterial repetitive intergenic consensus (ERIC) sequences, repetitive extragenic palindromic (REP) sequences, and the BOXA subunit of the BOX element (BOX) and analyzed using the product-moment correlation coefficient $(r)$. DNA homology groups correspond to those reported by Rademaker et al. (32). The type strain of Xanthomonas axonopodis pv. allii MAFF 311173 and X. axonopodis pv. citrumelo 3048 are noted in bold. Genotype groups 1 to 3 within X. axonopodis allii, alfalfae, and citrumelo are noted with brackets. $\mathrm{Xa}=$ Xanthomonas axonopodis. 
but not all, $X$. axonopodis pv. allii strains carry a plasmid of identical size (D. Gent, C. Ishimaru, and H. Schwartz, unpublished). Group 3 contains an amalgam of diverse $X$. axonopodis strains, including $X$. axonopodis pv. allii strains belonging to repPCR genotype groups 2, 4, and 5, X. axonopodis pv. citrumelo, and $X$. axonopodis pv. alfalfae. Strains included in this group were originally isolated from host plants in Asia, Africa, North and South America, Hawaii, and the East Caribbean. Strains of $X$. axonopodis pv. citrumelo in this group are weakly to moderately aggressive to their citrus hosts and belong to RFLP group E1 (9). $X$. axonopodis pvs. allii and alfalfae strains within this group also appear moderately to weakly aggressive to citrus.

$X$. axonopodis pv. allii appears to be well adapted to in planta multiplication and persistence in onion and is the only known $X$. axonopodis pathovar capable of inducing water soaking in this plant species. Culturable populations of $X$. axonopodis pv. allii were 10- to 1,000-fold greater in onion as compared with the other DNA homology group 9.2 strains ( $X$. axonopodis pvs. alfalfae, betlicola, and citrumelo) and nearly $7 \log$ units greater than the strains that are most divergent with DNA homology group 9.2 (X. axonopodis pv. vesicatoria) or outside of DNA homology group 9.2 (X. axonopodis pv. phaseoli). Under field conditions, $X$. axonopodis pv. allii persists epiphytically and endophytically, sometimes at populations as great as $10^{7} \mathrm{CFU} / \mathrm{g}$ on onion $(10,30)$, and can be damaging to seedling and mature onion plants $(2,10,28,29,40-43)$. This is in complete contrast to citrus bacterial spot, in which an aggressive strain of the pathogen, favorable environmental conditions, a highly susceptible host, and wounding appear to be prerequisites for disease development in citrus nurseries (13-21). The pathogen tends to only persist in and on Swingle citrumelo (Poncirus trifoliata $\times$ Citrus paradisi) $(8,19,20)$, produces little inoculum $(46)$, and rarely infects fruit under field conditions (21).

The citrus bacterial spot pathogen remained widespread in Florida citrus nurseries despite repeated eradication efforts $(12,13,17,18,39)$. Gabriel et al. (9) suggested that the primary host and source of $X$. axonopodis pv. citrumelo is not a rutaceous host. The close genetic, pathogenic, phenotypic, and serological relatedness among $X$. axonopodis pvs. allii, alfalfae, and citrumelo $(1,9,11,12,18,19,35)$ suggests these pathovars may have originated from a common ancestral strain. Interestingly, $X$. axonopodis pv. allii was recovered from onion in the east Caribbean (2931 ) and apparently garlic in Cuba (35) in the mid-1980s. Anecdotal evidence suggests that the pathogen may have been present in the region as early as $1971(31,44)$. It is tempting to speculate the source of the citrus bacterial spot pathogens that initiated epidemics in Florida in 1984 and later were X. axonopodis pv. allii strains introduced from a neighboring country or region where they were established on a primary host such as onion or garlic. However, Xanthomonas leaf blight has not been reported on onion in Florida, and we were unable to elicit water soaking on onion by inoculation with any $X$. axonopodis pv. citrumelo or alfalfae strain in this study. The $X$. axonopodis pv. citrumelo strains used in this study were collected and preserved nearly 20 years ago and may have lost their ability to induce water soaking on onion because of repeated selection on artificial growth media. In the absence of selection for virulence, these strains may have lost their ability to infect onion. This raises questions about the genetics of host specificity, where one or a few genes may govern host range and thus pathovar status. Host specificity or symptomology induced by closely related strains can be controlled by single genes in the "translucens" or "campestris" groups, respectively $(5,48)$.

The original inoculum source of $X$. axonopodis pv. citrumelo remains speculative. Nonetheless, we have established the close genetic and pathogenic relatedness among $X$. axonopodis DNA homology group 9.2 pathovars. Knowledge of this relationship may direct new hypotheses regarding the origin and appearance of new pathovars, and provides the foundation for future epidemiological studies of these closely related plant pathogens.

\section{ACKNOWLEDGMENTS}

Funding for this research was provided by the Colorado Onion Association, Arkansas Valley Growers and Shippers Association, and USDA/CSREES Crops at Risk Program Grant No. 2002-51100-01905, entitled "Integrated Management of Xanthomonas Leaf Blight of Onion by Cultural Practices, Disease Forecasting, and Biologically-Based Pesticides." We gratefully thank researchers and organizations who provided strains for this study.

\section{LITERATURE CITED}

1. Alvarez, A. M., Benedict, A. A., Mizumoto, C. Y., Pollard, L. W., and Civerolo, E. L. 1991. Analysis of Xanthomonas campestris pv. citri and X. c. citrumelo with monoclonal antibodies. Phytopathology 81:857-865.

2. Alvarez, A. M., Buddenhagen, I. W., Buddenhagen, E. S., and Domen, H. Y. 1978. Bacterial blight of onion, a new disease caused by Xanthomonas sp. Phytopathology 68:1132-1136.

3. Ausubel, F. M., Brent, R., Kingston, R. E., Moore, D. D., Seidman, J. G., Smith, J. A., and Struhl, K. 1998. Current Protocols in Molecular Biology. John Wiley \& Sons, Inc., Hoboken, NJ.

4. Bowen, P., Gibbs, H. A., and O'Garro, L. W. 1996. Garlic, chives, shallot, and leek are alternative hosts to Xanthomonas campestris, the pathogen of leaf blight of onion. Proc. Int. Congr. Plant Pathol. 7:696.

5. Chen, J., Roberts, P. D., and Gabriel, D. W. 1994. Effects of a virulence locus from Xanthomonas campestris $528^{\mathrm{T}}$ on pathovar status and ability to elicit blight symptoms on crucifers. Phytopathology 84:1458-1465.

6. DeFeyter, R., Kado, C. I., and Gabriel, D. W. 1990. Small, stable shuttle vectors for use in Xanthomonas. Gene 88:65-72.

7. Dye, D. W., Bradbury, J. F., Goto, M., Hayward, A. C., Lelliott, R. A., and Schroth, M. N. 1980. International standards for naming pathovars of phytopathogenic bacteria and a list of pathovar names and pathotype strains. Rev. Plant Pathol. 59:153-160.

8. Egel, D. S., Graham, J. H., and Riley, T. D. 1991. Population dynamics of strains of Xanthomonas campestris differing in aggressiveness on Swingle citrumelo and grapefruit. Phytopathology 81:666-671.

9. Gabriel, D. W., Kingsley, M. T., Hunter, J. E., and Gottwald, T. 1989. Reinstatement of Xanthomonas citri (ex Hasse) and X. phaseoli (ex Smith) to species and reclassification of all $X$. campestris pv. citri strains. Int. J. Syst. Bacteriol. 39:14-22.

10. Gent, D. H. 2004. Xanthomonas leaf blight of onion: Biology, epidemiology, and management. Ph.D. diss., Colorado State University, Fort Collins.

11. Gent, D. H., Schwartz, H. F., Ishimaru, C. A., Louws, F. J., Cramer, R. A., and Lawrence, C. B. 2004. Polyphasic characterization of Xanthomonas strains from onion. Phytopathology 94:184-195.

12. Gottwald, T. R., Alvarez, A. M., Hartung, J. S., and Benedict, A. A. 1991. Diversity of Xanthomonas campestris pv. citrumelo strains associated with epidemics of citrus bacterial spot in Florida citrus nurseries: Correlation of detached leaf, monoclonal antibody, and restriction fragment length polymorphism assays. Phytopathology 81:749-753.

13. Gottwald, T. R., and Graham, J. H. 1990. Spatial pattern analysis of epidemics of citrus bacterial spot in Florida citrus nurseries. Phytopathology 80:181-190.

14. Gottwald, T. R., Graham, J. H., Civerolo, E. L., Barrett, H. C., and Hearn, C. J. 1993. Differential host range reaction of citrus and citrus relatives to citrus canker and citrus bacterial spot determined by leaf mesophyll susceptibility. Plant Dis. 77:1004-1009.

15. Gottwald, T. R., Graham, J. H., and Richie, S. M. 1992. Relationship of leaf surface populations of strains of Xanthomonas campestris pv. citrumelo to development of citrus bacterial spot and persistence of disease symptoms. Phytopathology 82:625-632.

16. Gottwald, T. R., Graham, J. H., and Riley, T. D. 1997. The influence of spray adjuvants on exacerbation of citrus bacterial spot. Plant Dis. 81:1305-1310.

17. Gottwald, T. R., Miller, C., Brlansky, R. H., Gabriel, D. W., and Civerolo, E. L. 1989. Analysis of the spatial distribution of citrus bacterial spot in a Florida citrus nursery. Plant Dis. 73:297-303.

18. Graham, J. H., and Gottwald, T. R. 1990. Variation in aggressiveness of Xanthomonas campestris pv. citrumelo associated with citrus bacterial spot in Florida citrus nurseries. Phytopathology 80:190-196.

19. Graham, J. H., Gottwald, T. R., and Fardelmann, D. 1990. Cultivar-specific interactions for strains of Xanthomonas campestris from Florida that cause citrus canker and citrus bacterial spot. Plant Dis. 74:753-756.

20. Graham, J. H., Gottwald, T. R., Riley, T. D., and Achor, D. 1992. Penetration through leaf stomata and growth of strains of Xanthomonas campes- 
tris in citrus cultivars varying in susceptibility to bacterial diseases. Phytopathology 82:1319-1325.

21. Graham, J. H., Gottwald, T. R., Riley, T. D., and Bruce, M. A. 1992. Susceptibility of citrus fruit to citrus bacterial spot and citrus canker. Phytopathology 82:452-457.

22. Hartung, J. S., and Civerolo, E. L. 1989. Restriction fragment length polymorphisms distinguish Xanthomonas campestris strains isolated from Florida citrus nurseries from $X$. c. pv. citri. Phytopathology 79:793799.

23. Isakeit, T., Miller, M. E., Barnes, L. W., Dickstein, E. R., and Jones, J. B. 2000. First report of leaf blight of onion caused by Xanthomonas campestris in the continental United States. Plant Dis. 84:201.

24. Kadota, I., Uehara, K., Shinohara, H., and Nishiyama, K. 2000. Bacterial blight of Welsh onion: A new disease caused by Xanthomonas campestris pv. allii pv. nov. J. Gen. Plant Pathol. 66:310-315.

25. Louws, F. J., Bell, J., Medina-Mora, C. M., Smart, C. D., Opgenorth, D., Ishimaru, C. A., Hausbeck, M. K., de Bruijin, F. J., and Fulbright, D. W. 1998. rep-PCR-mediated genomic fingerprinting: A rapid and effective method to identify Clavibacter michiganensis. Phytopathology 88:862868.

26. Louws, F. J., Fulbright, D. W., Stephens, C. T., and de Bruijn, F. J. 1994. Specific genomic fingerprints of phytopathogenic Xanthomonas and Pseudomonas pathovars and strains generated with repetitive sequences and PCR. Appl. Environ. Microbiol. 60:2286-2295.

27. Louws, F. J., Fulbright, D. W., Stephens, C. T., and de Bruijin, F. J. 1995. Differentiation of genomic structure by rep-PCR fingerprinting to rapidly classify Xanthomonas campestris pv. vesicatoria. Phytopathology 85:528536.

28. Nunez, J. J., Gilbertson, R. L., Meng, X., and Davis, R. M. 2002. First report of Xanthomonas leaf blight of onion in California. Plant Dis. $86: 330$.

29. O'Garro, L. W., and Paulraj, L. P. 1997. Onion leaf blight caused by Xanthomonas campestris: Alternative hosts and resistant onion genotypes. Plant Dis. 81:978-982.

30. Paulraj, L., and O'Garro, L. W. 1992. Aspects of the epidemiology of a leaf blight of onion in Barbados. Pages 89-96 in: Proc. Annu. Conf. Barbados Soc. Technol. Agric., 10th. St. Micheal, Barbados.

31. Paulraj, L., and O'Garro, L. W. 1993. Leaf blight of onions in Barbados caused by Xanthomonas campestris. Plant Dis. 77:198-201.

32. Rademaker, J. L. W., Hoste, B., Louws, F. J., Kersters, K., Swings, J., Vauterin, L., Vauterin, P., and de Bruijn, F. J. 2000. Comparison of AFLP and rep-PCR genomic fingerprinting with DNA-DNA homology studies: Xanthomonas as a model system. Int. J. Syst. Bacteriol. 50:665-677.

33. Rademaker, J. L. W., Louws, F. J., and de Bruijn, F. J. 1999. Computer assisted pattern analysis of electrophoretic fingerprints and database construction. Pages 1-33 in: Molecular Microbial Ecology Manual. A. D. L.
Akkermans, J. D. van Elsas, and F. J. de Bruijn, eds. Kluwer Academic Publishers, Dordrecht, the Netherlands.

34. Rademaker, J. L. W., Louws, F. J., Schultz, M. H., Rossbach, U., Vauterin, L., Swings, J., and de Bruijn, F. J. A comprehensive species to strain taxonomic framework for Xanthomonas. Phytopathology (In press.)

35. Roumagnac, P., Gagnevin, L., Gardan, L., Sutra, L., Manceau, C., Dickstein, E. R., Jones, J. B., Rott, P., and Pruvost, O. 2004. Polyphasic characterization of xanthomonads isolated from onion, garlic and Welsh onion (Allium spp.) and their relatedness to different Xanthomonas species. Int. J. Syst. Evol. Microbiol. 54:15-24.

36. Roumagnac, P., Gagnevin, L., and Pruvost, O. 2000. Detection of Xanthomonas sp., the causal agent of onion bacterial blight, in onion seeds using a newly developed semi-selective isolation medium. Eur. J. Plant Pathol. 106:867-877.

37. Roumagnac, P., Pruvost, O., Chiroleu, F., and Hughes, G. 2004. Spatial and temporal analyses of bacterial blight of onion caused by Xanthomonas axonopodis pv. allii. Phytopathology 94:138-146.

38. Sanders, F. H., Langston, D. B., Brock, J. H., Gitaitis, R. D., Curry, D. E., and Torrance, R. L. 2003. First report of a leaf blight of onion caused by Xanthomonas spp. in Georgia. Plant Dis. 87:749.

39. Schoulties, C. L., Civerolo, E. L., Miller, J. W., Stall, R. E., Krass, C. J., Poe, S. R., and DuCharme, E. P. 1987. Citrus canker in Florida. Plant Dis. 71:388-394

40. Schwartz, H. F., and Otto, K. J. 1998. Onion bacterial disease management in Colorado. Pages 214-218 in: Proc. 1998 Natl. Onion (and other Allium) Res. Conf.

41. Schwartz, H. F., and Otto, K. 2000. First report of a leaf blight of onion by Xanthomonas campestris in Colorado. Plant Dis. 84:922.

42. Schwartz, H. F., Otto, K. L., and Gent, D. H. 2003. Relation of temperature and rainfall to development of Xanthomonas and Pantoea leaf blights of onion in Colorado. Plant Dis. 87:11-14.

43. Serfontein, J. J. 2001. Xanthomonas blight of onion in South Africa. Plant Dis. $85: 442$.

44. Small, W. 1973. A preliminary report on the onion blast disease in Barbados. Pages 389 in: Proc. Caribb. Food Crops Soc. Vol 11.

45. Thomas, W. D., Jr., and Weinhold, A. R. 1953. Xanthomonas striaformans, a new bacterial pathogen of onion. J. Colo.-Wyo. Acad. Sci. 4:22.

46. Timmer, L. W., Gottwald, T. R., and Zitko, S. E. 1991. Bacterial exudation from lesions of Asiatic citrus canker and citrus bacterial spot. Plant Dis. 75:192-195.

47. Vauterin, L., Hoste, B., Kersters, K., and Swings, K. 1995. Reclassification of Xanthomonas. Int. J. Syst. Bacteriol. 45:472-489.

48. Waney, V. R., Kingsley, M. T., and Gabriel, D. W. 1991. Xanthomonas campestris pv. translucens genes determining host-specific virulence and general virulence on cereals identified by Tn5-gusA insertion mutagenesis. Mol. Plant-Microbe Interact. 4:623-627. 